\title{
Water-use dynamics of an alien-invaded riparian forest within the summer rainfall zone of South Africa
}

\author{
Bruce C. Scott-Shaw ${ }^{1}$ and Colin S. Everson ${ }^{1,2}$ \\ ${ }^{1}$ Centre for Water Resources Research, School of Agricultural, Earth and Environmental Sciences, \\ University of KwaZulu-Natal, Private Bag X01, Scottsville, Pietermaritzburg 3209, South Africa \\ ${ }^{2}$ Department of Plant and Soil Sciences, University of Pretoria, Private Bag X20, \\ Hatfield, Pretoria 0028, South Africa
}

Correspondence: Bruce C. Scott-Shaw (brucecharlesss@gmail.com)

Received: 3 May 2018 - Discussion started: 28 May 2018

Revised: 18 December 2018 - Accepted: 21 January 2019 - Published: 18 March 2019

\begin{abstract}
In South Africa the invasion of riparian forests by alien trees has the potential to affect the country's limited water resources. Tree water-use measurements have therefore become an important component of recent hydrological studies. It is difficult for South African government initiatives, such as the Working for Water (WfW) alien clearing programme, to justify alien tree removal and implement rehabilitation unless hydrological benefits are known.

The objective of this study was to investigate the water use (transpiration rates) of a selection of introduced and indigenous tree species and quantify the hydrological benefit that could be achieved through a suitable rehabilitation programme. Consequently water use within a riparian forest in the upper Mgeni catchment of KwaZulu-Natal in South Africa was monitored over a 2-year period. The site consisted of an indigenous stand of eastern mistbelt forest that had been invaded by Acacia mearnsii, Eucalyptus nitens and Solanum mauritianum. The heat ratio method of the heat pulse velocity (HPV) sap flow technique and the stem steady state (SSS) techniques were used to measure the sap flow of a selection of indigenous and introduced species. The indigenous trees at New Forest, South Africa, showed clear seasonal trends in the daily sap flow rates varying from 8 to $25 \mathrm{~L} \mathrm{day}^{-1}$ in summer (sap flow being directly proportional to tree size). In the winter periods this was reduced to between 3 and $6 \mathrm{Lday}^{-1}$ when limited energy flux was available to drive the transpiration process. The water use in the A. mearnsii and E. grandis trees showed a slight seasonal trend, with a high flow during the winter months in contrast to the indigenous species. The water use in the understorey
\end{abstract}

indicated that multi-stemmed species used up to $12 \mathrm{~L} \mathrm{day}^{-1}$. Small alien trees $(<30 \mathrm{~mm})$ A. mearnsii and $S$. mauritianum used up to $4 \mathrm{Lday}^{-1}$ each. The total accumulated sap flow per year for the three individual $A$. mearnsii and E. grandis trees was 6548 and $7405 \mathrm{~L} \mathrm{a}^{-1}$ respectively. In contrast, the indigenous species averaged $2934 \mathrm{La}^{-1}$, clearly demonstrating the higher water use of the introduced species. After spatial upscaling, it was concluded that, at the current state of invasion ( $21 \%$ of the stand being alien species), the stand used $40 \%$ more water per unit area than if the stand were in a pristine state. If the stand were to be heavily invaded at the same stem density of the indigenous forest, a $100 \%$ increase in water use would occur over an average rainfall year.

\section{Introduction}

A total of 10 million ha of South Africa has been invaded by 180 alien species, which is over $8 \%$ of the country's total area (van Wilgen et al., 2001). The majority of this invasion extent is within riparian areas that have readily available water and are difficult to manage (Kotzé et al., 2010). In South Africa there is a limited understanding of the extent to which tree species (particularly those in the riparian area) contribute to total evaporation (ET). As such, it is difficult for government organizations and scientists to justify alien tree removal and rehabilitation, unless a known hydrological benefit can be demonstrated. The deep fertile soils, with high soil moisture contents associated with riparian areas, make them ideal for plant establishment and growth (Ev- 
erson et al., 2007). In South Africa, these areas are extremely vulnerable to invasion by pioneer plant species, particularly species that have historically been introduced for commercial forestry. In South Africa, there is a widespread belief (which has been supported by numerous studies: Olbrich et al., 1996; Dye et al., 2001, 2008; Everson et al., 2007; Gush and Dye, 2008, 2009; Gush et al., 2015) that indigenous tree species, in contrast to the introduced tree species, use less water and should be planted more widely in land rehabilitation programmes. Little research has been undertaken on the riparian area where the availability of water to trees is often not limited (except in severe drought conditions).

The benefits of healthy riparian zones in providing basic ecosystem services are well known (Askey-Dorin et al., 1999; Richardson et al., 2005). These benefits and the impacts of degradation through alien plant invasions were fully described in a study by Scott-Shaw et al. (2017) on the water use of plants in the Mediterranean climate of the Western Cape region of South Africa. Here we summarize the most important aspects relevant to this study.

Commercial forestry has been blamed for increasing the green water (water lost by total evaporation) and decreasing the blue water (water in rivers and dams) in areas across South Africa (Jewitt, 2006). For these reasons, invasive alien plants (IAPs), particularly introduced commercial trees, are considered to be a major threat to water resources and biodiversity.

There is a widespread belief in South Africa and globally that indigenous tree species, in contrast to the introduced trees, are water efficient and should be planted more widely in land restoration programmes. This is based on observations that indigenous trees are generally slow growing and that growth and water use are broadly linked (Everson et al., 2008; Gush, 2011).

At the ecosystem scale, a comprehensive review of numerous internationally published studies indicates that invasive species use up to $189 \%$ more water than indigenousdominated stands, particularly in tropical moist forests (Nosetto et al., 2005; Yepez et al., 2005; Fritzsche et al., 2006). These findings, typically outside of South Africa, are limited to mostly herbaceous species with very few recent studies focusing on measurement of introduced trees. In the high-rainfall areas of South Africa, invasive alien plants growing in riparian areas $\left(5726 \mathrm{~km}^{2}\right)$ are estimated to reduce annual streamflow by $523 \times 10^{6} \mathrm{~m}^{3}$ with a predicted annual reduction estimated to be as high as $1314 \times 10^{6} \mathrm{~m}^{3}$ if allowed to reach a fully invaded state (Cullis et al., 2007).

Management of invaded riparian zones can result in hydrological gains disproportionately greater than the catchment area affected, with up to 3 times more streamflow yield than upslope areas (Scott and Lesch, 1996; Scott, 1999).

For many field and modelling applications, accurate estimates of total evaporation are required, but are often lacking. Sap flux density measurements give precise information on flow directions as well as spatial and temporal flow distri- bution (Vandegehuchte and Steppe, 2013). The heat pulse velocity (HPV) method is the most accurate of the available methods when compared against gravimetric methods (Steppe et al., 2010; Vandegehuchte and Steppe, 2013).

While extensive research has been undertaken on the water use of terrestrial ecosystems, little is known about riparian tree water use and growth for both indigenous and introduced tree species. This gap in knowledge has led to uncertainty and contention over riparian restoration and rehabilitation techniques. In this research, the water use was measured for various indigenous and introduced species that have been identified as economically or ecologically viable. Results from this study provide substance that may facilitate riparian habitat rehabilitation. The the New Forest site in KwaZulu-Natal, South Africa, is part of a Working for Water clearing programme. The government-funded WfW programme clears catchment areas of invasive alien plants with the aim of restoring hydrological functioning while also providing poverty relief to local communities through job creation (Turpie et al., 2008). The aim of this study was to quantify the potential hydrological benefit of the conversion of invaded stands to more pristine stands for forest management practices.

\section{Methods}

An overview of the study site, sampling design and equipment used to carry out the study has been provided in this section. Details on the heat pulse velocity technique have been documented in a previous paper (Scott-Shaw et al., 2017) and will not been repeated here.

\subsection{The study area}

The the New Forest riparian area is located at latitude $29^{\circ} 28^{\prime} 30^{\prime \prime} \mathrm{S}$ and longitude $29^{\circ} 52^{\prime} 48^{\prime \prime} \mathrm{E}$ at approximately $1760 \mathrm{~m}$ a.s.l. (above sea level) (Fig. 1). The riparian area occurs along a tributary to the upper Umgeni River, within Quaternary Catchment (QC) U20A. The New Forest riparian area falls within the eastern mistbelt forest zone. This forest type when in a pristine state is typically dominated by Leucosidea sericea, Halleria lucida, Celtis africana and Afrocarpus falcatus. Mistbelt forest is a species-rich, multilayered forest and has a dense shrubby understorey. The forests show a mix of coarse-grained canopy gap characteristics and disturbance-driven dynamics and fine-grained regeneration characteristics (Mucina and Rutherford, 2006). The surrounding natural areas are covered by Highland Sourveld (Acocks, 1988) or Drakensberg Foothill Moist Grassland (Mucina and Rutherford, 2006). The study site is typical of invasive alien plant invasion, whereby plantations have been grown in traditionally fire-dominated grasslands and have subsequently invaded the surrounding riparian areas. Eastern mistbelt forests can be characterized as cool, tall in- 


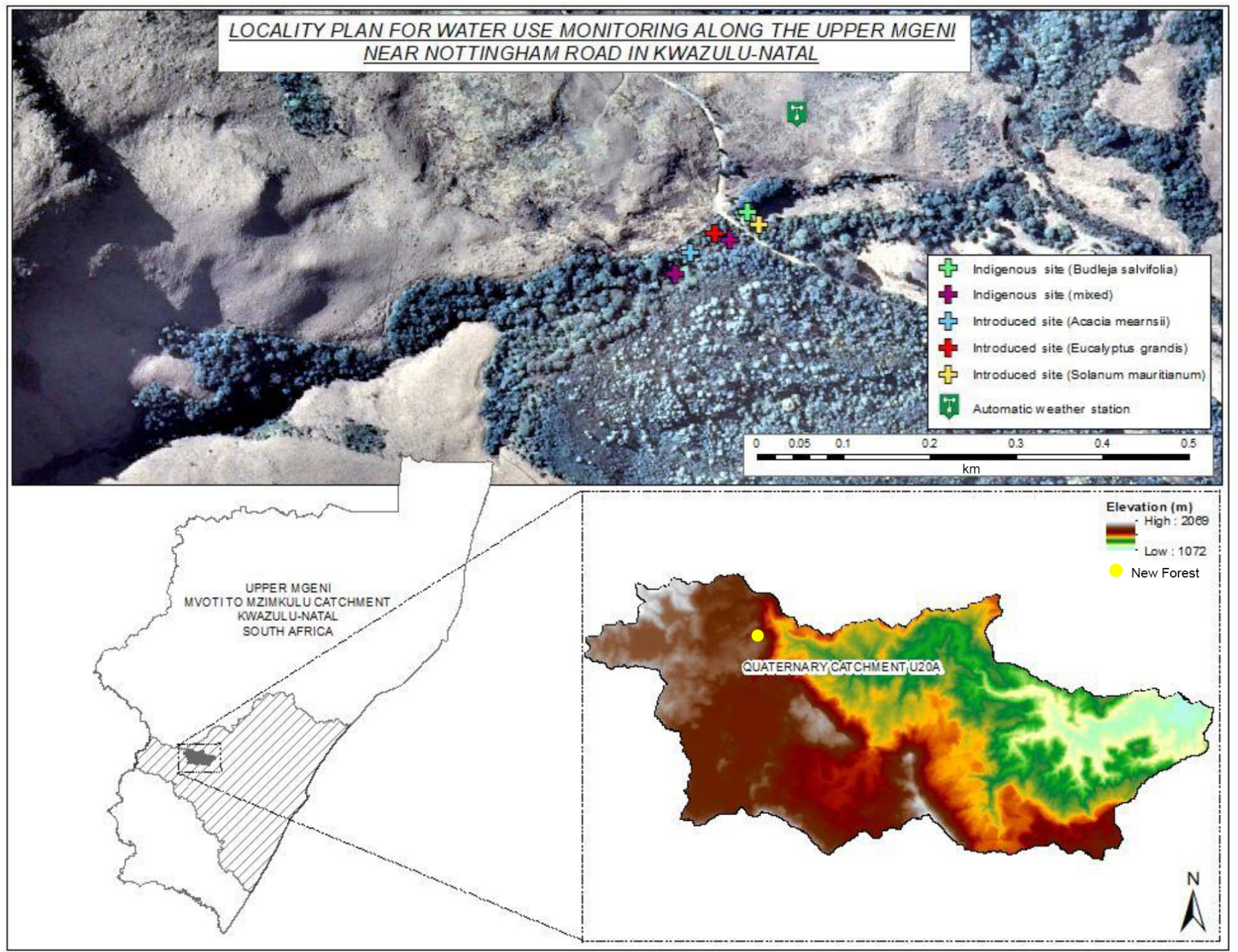

Figure 1. Location of the New Forest farm research area within KwaZulu-Natal, South Africa.

land forests (Pooley, 2003). The mountain slopes of the area consist of fractured dolerite dykes and basaltic outpourings (Crowson, 2008). The soils show evidence of high precipitation and age with shallow unstructured soils occurring on the upper slopes, red apedal soils on the midslope and soils with an underlying G-horizon dominating the low-lying areas.

Approximately $80 \%$ of the precipitation occurs in the summer months (October to March), which mostly consists of orographically induced and squall-line thunderstorms (Schulze, 1982). Interception from mist makes a large contribution to the seasonal precipitation and determines the distribution of the mistbelt forest. The long-term mean annual precipitation (MAP) is between 941 and $1000 \mathrm{~mm} \mathrm{a}^{-1}$ with a distinct dry season from May to August. Average air temperatures range from $25.2^{\circ} \mathrm{C}$ in the summer to $16.9^{\circ} \mathrm{C}$ in winter, with the highest air temperatures occurring on the northfacing slopes. Cool mountain winds occur at night with warm up-valley winds occurring during the day (Crowson, 2008). Strong berg (westerly) winds are prevalent during August to
September and play a significant role in the spread of fires (Schulze, 1982).

The New Forest farm is privately owned. The area south of the Umgeni tributary has been planted with Acacia mearnsii and Pinus patula since the 1960s. The riparian area has since been heavily invaded (>20\%) with A. mearnsii, Eucalyptus nitens and Solanum mauritianum. Riparian invasive alien tree clearing by WfW has been ongoing in the area.

\subsection{Sampling design}

Five sites, each representing frequently occurring indigenous and introduced tree species, were instrumented for water-use monitoring. These trees included a size range of invasive $A$. mearnsii and $E$. nitens trees: a selection of common indigenous trees such as Gymnosporia buxifolia, Celtis africana and Searsia pyroides and a selection of trees growing in the understorey (S. mauritianum, A. mearnsii and Buddleja salviifolia). As the sites were in close proximity to each other, 
there were no variations in soil, climate and access to water between the sites. The leaf area index (LAI) within this stand was 3.1 during the summer months with a reduction to 2.2 during the winter months due to the presence of deciduous species. There was little variation in LAI throughout the forest due to a uniform invasion by introduced trees and the disturbed nature of the indigenous species across the stand.

The trees within the riparian forest were in a disturbed state. The overall canopy height of the indigenous species was low, ranging from 4.1 to $8.3 \mathrm{~m}$. The invasive species were significantly taller, ranging from 13.1 to $16.6 \mathrm{~m}$. The physical characteristics of each monitored tree are provided in Table 1. There was variability between the stem moisture content and wood density between species, which can be explained by the different physical characteristics of the trees measured (variations in sap wood depth and active xylem concentration). A forest ecology study (Everson et al., 2016) undertaken at New Forest compiled stem density measurements for regrowth forest, invaded riparian areas and on S. mauritianum-dominated plots. The findings indicated that, in the riparian forest, there was a density of 1632 stems ha $^{-1}$ of invasive species, with 6090 stems ha $^{-1}$ of indigenous species. In the $S$. mauritianum plots, there was a density of 1337 stems ha ${ }^{-1}$ of the invasive species, with 2600 stems ha $^{-1}$ of the remaining indigenous species.

\subsection{Meteorological station}

A meteorological station was established on 19 September 2012 at the New Forest farm in a nearby natural grassland, $250 \mathrm{~m}$ from the tree monitoring sites. Rainfall using a tipping bucket rain gauge (TE525, Texas Electronics Inc., Dallas, Texas, USA) was measured at a height of $1.2 \mathrm{~m}$ from the ground. Air temperature and relative humidity (HMP45C, Vaisala Inc., Helsinki, Finland), solar irradiance (LI-200, LI-COR, Lincoln, Nebraska, USA), net radiation (NR-Lite, Kipp and Zonen, Delft, the Netherlands), and wind speed and direction (Model 03002, R.M. Young, Traverse City, Michigan, USA) were all measured at a height of $2 \mathrm{~m}$ from the ground. These were measured at a $10 \mathrm{~s}$ interval and the appropriate statistical outputs were recorded every hour. A flat and uniform short grassland area which was regularly mowed was selected to meet the requirement for FAO 56 reference evaporation calculation.

\subsection{Tree water-use measurements}

A heat pulse velocity system using the heat ratio algorithm (Burgess et al., 2001) was set up to monitor long-term sap flow on all of the selected trees over a 2-year period. The instrumentation is described further by Clulow et al. (2013) and Scott-Shaw et al. (2017) and included hourly measurements of sap flow heater trace using a pair of type-T thermocouple probes. Regular maintenance was undertaken to ensure sufficient power and operation of the equipment. An increment borer was used to take non-destructive samples for sapwood depth, tree age, wood density and moisture content (described by Marshall, 1958), as well as to allow for upscaling of probe measurements to whole-tree water use $\left(\mathrm{L} \mathrm{h}^{-1}\right)$. Non-functional or damaged xylem (referred to as wounding) around the thermocouples was accounted for using woundcorrection coefficients described by Burgess (2001). Tree growth was recorded during each site visit by measuring diameter at breast height and canopy height using a VL402 hypsometer (Haglöf, Sweden). Leaf area index using a LAI2200 (LI-COR, Lincoln, Nebraska, USA) was measured regularly throughout the stand.

The stem steady state (SSS) technique, which estimates sap flow by solving a heat balance for a segment of stem that is supplied with a known amount of heat (Grime and Sinclair, 1999), was implemented on the smaller trees in the understorey that were not quantifiable using the HPV technique. Two Dynamax Flow 32-K systems (Dynamax, Houston, TX, USA) were installed at New Forest. Each of these systems was powered by a $12 \mathrm{~V} 100$ Ah battery and consisted of a CR1000 data logger (Campbell Scientific Inc.) and an AM16/32B multiplexer. A voltage control unit regulated the voltage output depending on the number of collars and the size of the collars. The gauge's insulating sheath (referred to as a "collar") contains a system of thermocouples that measure temperature gradients associated with conductive heat losses vertically (up and down the stem) and radially through the sheath (Allen and Grime, 1994). A foam insulation and weather shield were installed around the stem in order to sufficiently minimize extraneous thermal gradients that could influence the heated section of the stem (Smith and Allen, 1996). The conduction of heat vertically upwards and downwards was calculated by measuring voltages which corresponded to the temperature difference between two points above and below the heater (Savage et al., 2000). The radial heat was calculated by measuring the temperature difference of the insulated layer surrounding the heater (Savage et al., 2000). Finally, the voltage applied to the heater was measured. These measurements allowed the energy flux $\left(\mathrm{J} \mathrm{s}^{-1}\right)$ to be calculated (Savage et al., 2000).

\subsection{Soil water measurements}

Hourly volumetric soil water contents (VWCs) were recorded at sites 1 and 2 within the riparian forest with three time domain reflectometry (TDR) probes (CS 615, Campbell Scientific Inc.) installed horizontally at each site. The probes were installed at depths of $0.1,0.3$ and $0.5 \mathrm{~m}$ below the litter layer, due to shallow soils at the site. A thick litter layer was observed throughout the site consisting of mostly indigenous leaves and large broken branches from cattle and climatic disturbances. The hourly volumetric water content measurements provided an understanding of the responses of trees to rainfall events or stressed conditions. Additional soil sam- 
Table 1. Tree physiology and specific data required for the calculation of sap flow and upscaling.

\begin{tabular}{|c|c|c|c|c|c|c|c|}
\hline $\begin{array}{l}\text { Indigenous } \\
\text { forest (site 1) }\end{array}$ & $\begin{array}{r}\text { Diameter } \\
(\mathrm{mm})\end{array}$ & $\begin{array}{l}\text { Size } \\
\text { class }\end{array}$ & $\begin{array}{l}\text { Growth } \\
\text { stage }\end{array}$ & $\begin{array}{l}\text { Moisture } \\
\text { fraction }\end{array}$ & $\begin{array}{c}\text { Average } \\
\text { wounding }\end{array}$ & $\begin{array}{c}\text { Wood } \\
\text { density } \\
\left(\mathrm{g} \mathrm{cm}^{-3}\right)\end{array}$ & $\begin{array}{c}\text { Representative } \\
\text { stem density } \\
\left(\text { stems ha }^{-1}\right)\end{array}$ \\
\hline * Searsia pyroides & 98 & Small & $\mathrm{S}$ & 0.41 & 3.1 & 0.60 & 6090 \\
\hline * Gymnosporia buxifolia & 114 & Small & $\mathrm{C}$ & 0.44 & 2.6 & 0.65 & \\
\hline${ }^{*}$ Gymnosporia buxifolia & 58 & Small & $\mathrm{C}$ & 0.44 & 2.6 & 0.66 & \\
\hline \multicolumn{8}{|l|}{$\begin{array}{l}\text { Introduced/alien } \\
\text { forest (site 2) }\end{array}$} \\
\hline *Acacia mearnsii & 131 & Medium & $\mathrm{S}$ & 0.48 & 3.0 & 0.69 & 1632 \\
\hline *Acacia mearnsii & 166 & Medium & $S$ & 0.47 & 3.0 & 0.69 & \\
\hline \multicolumn{8}{|l|}{$\begin{array}{l}\text { Indigenous forest } \\
\text { (site 3) }\end{array}$} \\
\hline${ }^{*}$ Celtis africana & 102 & Medium & $\mathrm{S}$ & 0.49 & 4.8 & 0.68 & 6090 \\
\hline${ }^{*}$ Kiggelaria africana & 50 & Medium & $\mathrm{P}$ & 0.46 & 3.1 & 0.69 & \\
\hline${ }^{*}$ Leucosidea sericea & 212 & Large & $\mathrm{C}$ & 0.47 & 2.8 & 0.64 & \\
\hline \multicolumn{8}{|l|}{$\begin{array}{l}\text { Introduced/alien } \\
\text { forest (site 4) }\end{array}$} \\
\hline *Eucalyptus nitens & 165 & Small & $\mathrm{S}$ & 0.51 & 3.8 & 0.71 & 1632 \\
\hline *Eucalyptus nitens & 96 & Small & $\mathrm{P}$ & 0.51 & 3.9 & 0.71 & \\
\hline \multicolumn{8}{|l|}{$\begin{array}{l}\text { Mixed understorey } \\
\text { (site 5) }\end{array}$} \\
\hline${ }^{\#}$ Buddleja salviifolia & $28^{+}$ & Small & $\mathrm{S}$ & $\mathrm{n} / \mathrm{a}$ & $\mathrm{n} / \mathrm{a}$ & $\mathrm{n} / \mathrm{a}$ & 2600 \\
\hline${ }^{\#}$ Solanum mauritianum & 25 & Small & $\mathrm{P}$ & $\mathrm{n} / \mathrm{a}$ & $\mathrm{n} / \mathrm{a}$ & $\mathrm{n} / \mathrm{a}$ & - \\
\hline${ }^{\#}$ Solanum mauritianum & 10 & Small & $\mathrm{P}$ & $\mathrm{n} / \mathrm{a}$ & $\mathrm{n} / \mathrm{a}$ & $\mathrm{n} / \mathrm{a}$ & - \\
\hline${ }^{\#}$ Solanum mauritianum & 19.1 & Small & $\mathrm{P}$ & $\mathrm{n} / \mathrm{a}$ & $\mathrm{n} / \mathrm{a}$ & $\mathrm{n} / \mathrm{a}$ & 1337 \\
\hline${ }^{\#}$ Solanum mauritianum & 26.7 & Small & $\mathrm{P}$ & $\mathrm{n} / \mathrm{a}$ & $\mathrm{n} / \mathrm{a}$ & $\mathrm{n} / \mathrm{a}$ & - \\
\hline${ }^{\#}$ Acacia mearnsii & 25.6 & Small & $\mathrm{P}$ & $\mathrm{n} / \mathrm{a}$ & $\mathrm{n} / \mathrm{a}$ & $\mathrm{n} / \mathrm{a}$ & - \\
\hline
\end{tabular}

* indicates that the HPV technique was used and ${ }^{\#}$ indicates that the stem steady state (SSS) technique was used. ${ }^{+}$indicates average stem diameter for multi-stemmed trees. Growth stage is represented by primary (P), secondary (S) or climax (C). n/a indicates that the measurement parameter was not applicable for the technique used.

ples were taken to determine the distribution of roots, soil bulk density and soil water content.

\subsection{Upscaling tree water use}

Although the riparian stand had a heterogeneous composition, the availability of detailed stem density measurements (Everson et al., 2016) allowed for a methodology to be followed based on relevant upscaling studies (Ford et al., 2004; Miller et al., 2007):

- Medoid (representative of the population) trees were selected for sap flow measurement:

a. most commonly occurring indigenous species (canopy and understorey),

b. most commonly occurring introduced species (canopy and understorey) and

c. a range of size classes for each species.
- A species density analysis was undertaken (species and diameter $(>50 \mathrm{~mm})$ in multiple $400 \mathrm{~m}^{2}$ plots).

- A relationship was derived between the measured whole-tree water use (using HPV and SSS) and each representative size class and species class identified in the density measurements. This allowed for the estimation of the stand water flux ( $\left.Q_{\text {stand }}\right)$.

- The $Q_{\text {stand }}$ was divided by the plot area $\left(400 \mathrm{~m}^{2}\right)$ to allow for the estimation of water use per unit area.

Techniques that measure total evaporation over a spatial area are usually ideal for upscaling sap flow measurements. However, at sites with limited aerodynamic fetch common in riparian areas, techniques such as eddy covariance may not always be used in the upscaling process. With the availability of detailed stem density data, upscaling whole-tree measurements to stand-level measurements can be done. However, 


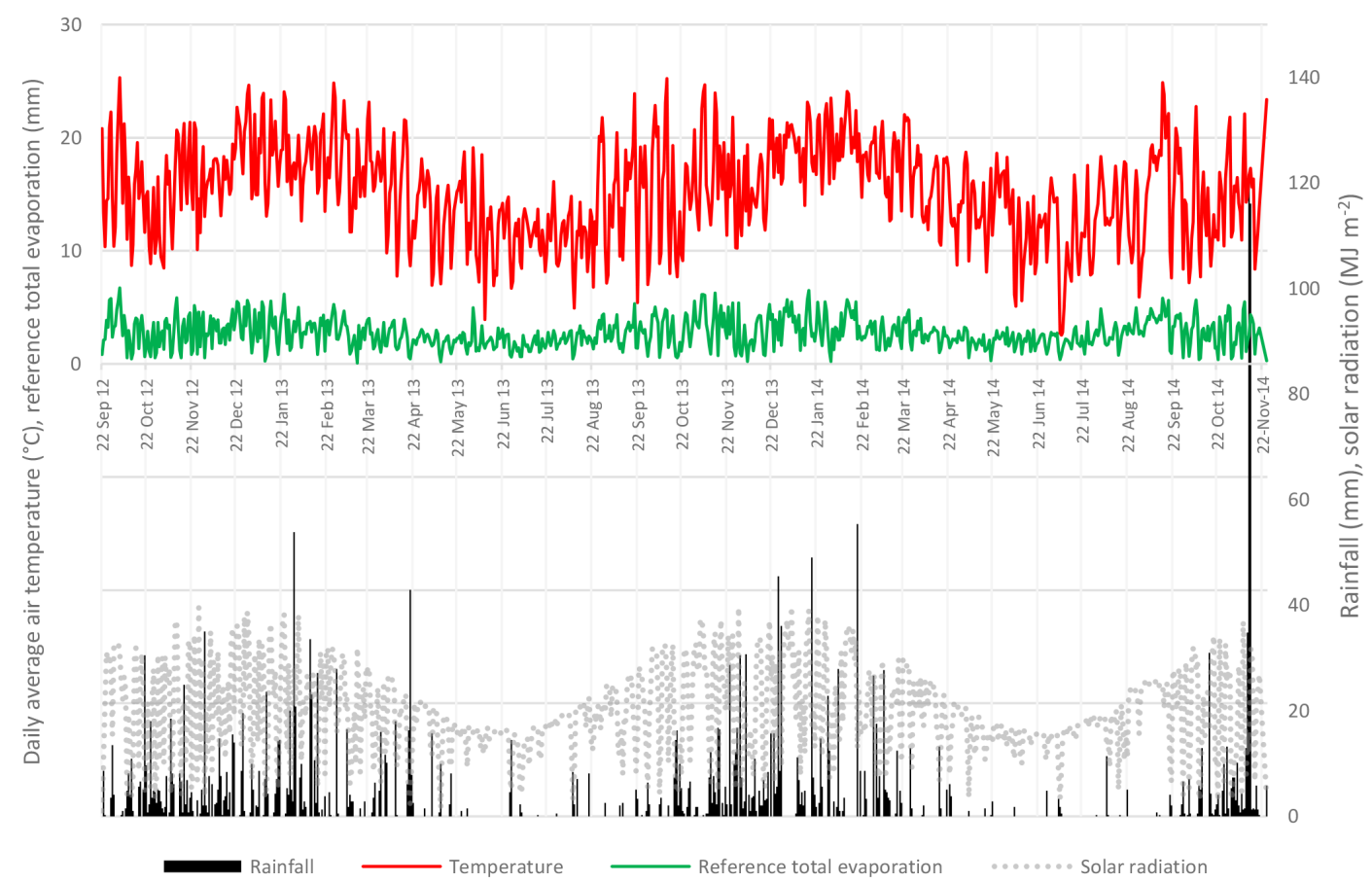

Figure 2. The daily rainfall, solar radiation, average air temperatures and reference total evaporation at New Forest.

limitations exist regarding the equipment available to maximize replications.

\section{Results}

\subsection{Weather conditions during the study period}

The historical mean annual precipitation for the New Forest area is $941 \mathrm{~mm}$. During the 2-year monitoring period the area received 1164 and $1110 \mathrm{~mm} \mathrm{a}^{-1}$ for 2013 and 2014 respectively. The rainfall distribution had a strong seasonal trend throughout the 2 years with an exceptionally high amount of $120 \mathrm{~mm} \mathrm{day}^{-1}$ in November 2014 (Fig. 2). The daily solar radiation peaked at $39 \mathrm{MJ} \mathrm{m}^{-2}$ following the same seasonal trend to that of the daily air average temperatures.

During periods of high solar radiation, the water vapour pressure deficit was high and correlated to peaks in transpiration rates. An average daily air temperature of $18.4^{\circ} \mathrm{C}$ was recorded at New Forest in the summer months. During these months, daily maximum air temperatures occasionally exceeded $30^{\circ} \mathrm{C}$. During the winter months, the air temperatures averaged $11.7^{\circ} \mathrm{C}$ due to numerous days with low solar radiation. Periods of low solar radiation correspond to overcast and/or rainfall periods and would likely result in little to no transpiration occurring. The daily reference total evaporation $\left(\mathrm{ET}_{\mathrm{o}}\right)$, derived from data captured on site, averaged approximately $1 \mathrm{~mm} \mathrm{day}^{-1}$ in the winter period to $5 \mathrm{~mm}_{\text {day }}{ }^{-1}$ during the summer period. The monthly climate data illustrates the seasonal rainfall and air temperature trend (Fig. 3). The seasonal distribution of rainfall is important as it is during these periods of water scarcity when the vegetative water use becomes significant.

\subsection{Tree water use}

The radial heat pulse velocity of a G. buxifolia was measured over a short summer period (Fig. 4). The velocity of water moving through the tree was highest (up to $20 \mathrm{~cm} \mathrm{~h}^{-1}$ ) nearest to the bark. Probes inserted deeper in the tree $(>15 \mathrm{~mm})$ measured very little flow, suggesting that there was less active xylem at these depths, resulting in a small sapwood area. During the winter period the radial heat pulse velocity of $A$. mearnsii had maximal flow at $25 \mathrm{~mm}$ below the bark (Fig. 5). There was still flow occurring at a depth of $35 \mathrm{~mm}$, indicating a much bigger sapwood area than that of the indigenous tree. Furthermore, the sap velocity was high $\left(>20 \mathrm{~cm} \mathrm{~h}^{-1}\right)$, even during the dry winter period. These findings also indicated that correct probe placement is essential to accurately representing the entire sapwood area of each tree.

Individual whole-tree water use showed a clear seasonal water-use trend for the semi-deciduous and deciduous indigenous species (Fig. 6). This was attributed to fewer daylight hours and less heat units during the winter months than in the summer months, resulting in reduced available energy and therefore limiting the transpiration process. The daily water use of $S$. pyroides averaged $8 \mathrm{~L} \mathrm{day}^{-1}$ in summer compared to $3 \mathrm{Lday}^{-1}$ in winter, resulting in an accumulated total water use of $1639 \mathrm{La}^{-1}$ (Fig. 6a). The deciduous $C$. africana used large amounts of water in the summer, with 


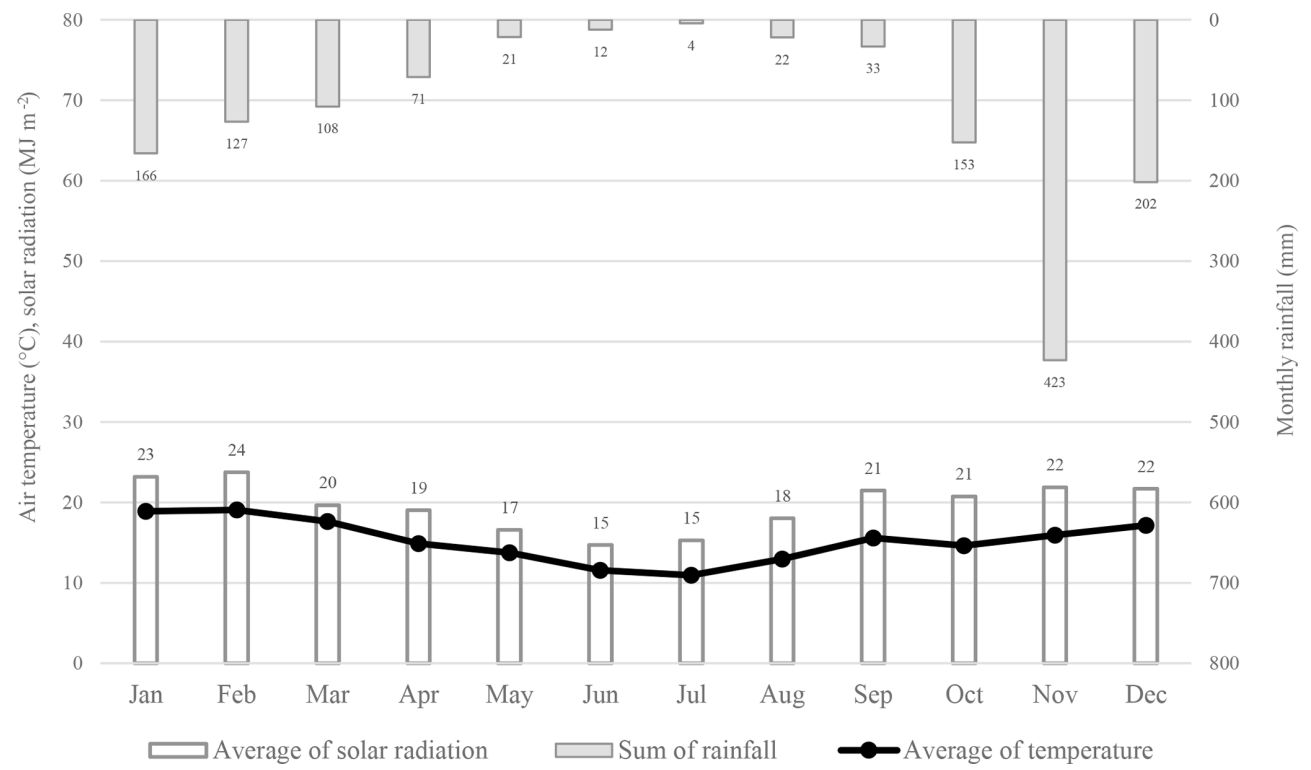

Figure 3. The monthly rainfall, monthly solar radiant density and average monthly air temperatures at New Forest averaged over 2 years.

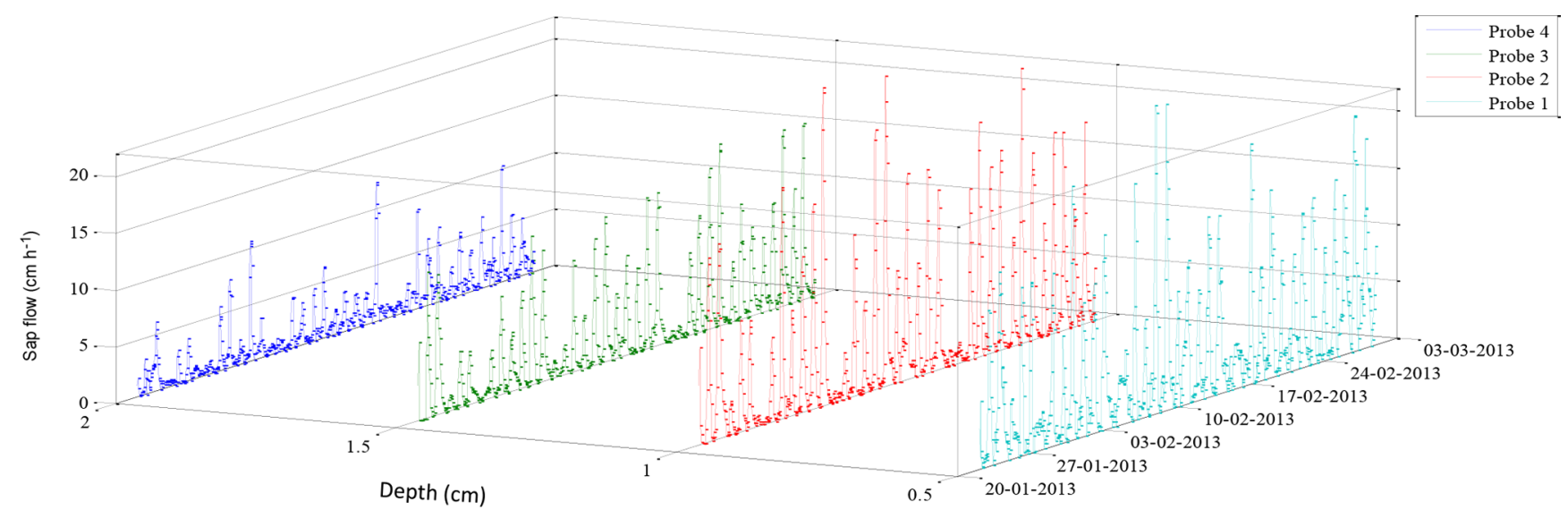

Figure 4. Hourly heat pulse velocity of a G. buxifolia $(\varnothing: 114 \mathrm{~mm})$ at New Forest.

an average of $25 \mathrm{Lday}^{-1}$. In the winter periods, after leaf fall, this species used no water, resulting in a reduction of the total annual water use $\left(4307 \mathrm{~L} \mathrm{a}^{-1}\right)$. In contrast, G. buxifolia used approximately $15 \mathrm{Lday}^{-1}$ in summer compared to $6 \mathrm{~L} \mathrm{day}^{-1}$ in winter, resulting in an accumulated total water use of $3870 \mathrm{~L} \mathrm{a}^{-1}$ over the same period (Fig. 6a, b, c).

The introduced $A$. mearnsii of a similar stem diameter showed little seasonal variation (Fig. 6d). This tree averaged $22 \mathrm{~L} \mathrm{day}^{-1}$ during summer periods and $14 \mathrm{Lday}^{-1}$ during winter periods, yielding a total of $5743 \mathrm{~L} \mathrm{a}^{-1}$, which is higher than that of the indigenous species and comparable to other large introduced species measured throughout South Africa (Gush et al., 2015).

With regards to the understorey, the daily water use of the multi-stemmed B. salviifolia, measured using the SSS technique, was the highest (up to $12 \mathrm{~L} \mathrm{day}^{-1}$ ) (Fig. 7). This tree, although short, had the greatest canopy area due to its lateral growth patterns with its numerous stems. In comparison, the smaller A. mearnsii used considerably less water, with a peak of $4 \mathrm{Lday}^{-1}$. The three $S$. mauritianum trees were highly variable, ranging from very low flows $\left(0.4 \mathrm{~L} \mathrm{day}^{-1}\right)$ to in excess of $4 \mathrm{Lday}^{-1}$. Although these values are small in comparison to the larger trees measured, they do show the importance of the understorey in-stand measurements. These trees, particularly the $S$. mauritianum, have a high density, suggesting that the cumulative water use of these trees is important when scaling up to the total forest water use.

The daily summer water use of indigenous trees at site 1 (Table 2) showed low water use with an average of between 9 and $15 \mathrm{Lday}^{-1}$ in the summer months. Likewise, the indigenous trees at site 3 were low water users. Despite being deciduous, the $C$. africana used the most water of all 


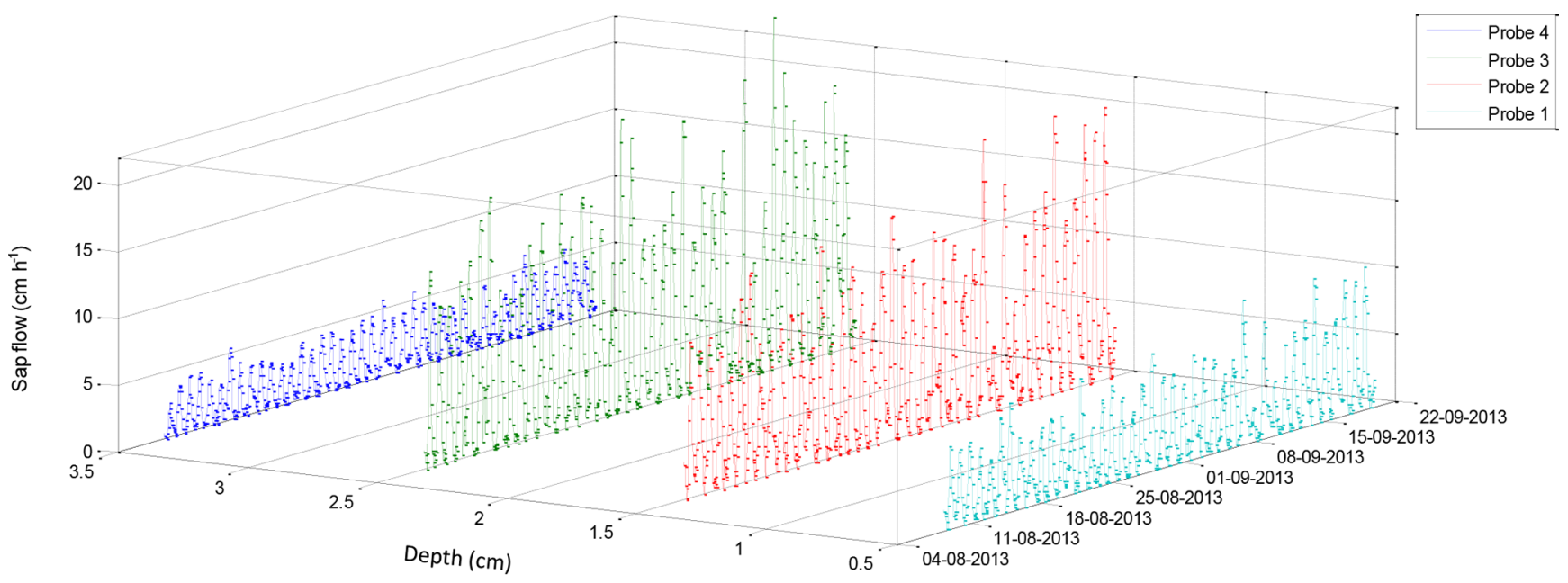

Figure 5. Hourly heat pulse velocity of an A. mearnsii (Ø: $131 \mathrm{~mm})$ at New Forest.

Table 2. Sap flow (daily and accumulated) for each species measured at New Forest.

\begin{tabular}{llrrrrr}
\hline $\begin{array}{l}\text { Forest type/ } \\
\text { location }\end{array}$ & Species & $\begin{array}{r}\text { Diameter } \\
(\mathrm{mm})\end{array}$ & $\begin{array}{r}\text { Daily average } \\
\text { summer sap } \\
\text { flow }\left(\mathrm{Ld}^{-1}\right)\end{array}$ & $\begin{array}{r}\text { Daily average } \\
\text { winter sap } \\
\text { flow }\left(\mathrm{Ld}^{-1}\right)\end{array}$ & $\begin{array}{r}\text { Standard } \\
\text { deviation }\end{array}$ & $\begin{array}{r}\text { Annual } \\
\text { accumulated sap } \\
\text { flow }\left(\mathrm{La} \mathbf{a}^{-1}\right)\end{array}$ \\
\hline Indigenous & S. pyroides & 98 & 9 & 3.6 & 1.06 & 1639 \\
forest (site 1) & G. buxifolia & 114 & 15 & 3.9 & 0.82 & 3901 \\
& G. buxifolia & 58 & 12 & 3.8 & 0.96 & 283 \\
\hline Introduced/alien & A. mearnsii & 131 & 18 & 15 & 1.10 & 5786 \\
forest (site 2) & A. mearnsii & 166 & 23 & 17 & 0.99 & 7310 \\
\hline Indigenous Forest & C. africana & 102 & 22 & 0.9 & 2.43 & 4307 \\
(site 3) & K. africana & 50 & 10 & 3.7 & 1.45 & 2508 \\
& L. sericea & 212 & 9 & 4 & 0.32 & 2369 \\
\hline Introduced/alien & E. grandis & 165 & 27 & 15 & 1.41 & 7668 \\
forest (site 4) & E. grandis & 96 & 25 & 14 & 1.64 & 7142 \\
\hline Mixed understorey & B. salviifolia & 28 & 5.9 & 5.5 & 2.82 & 2080 \\
(site 5) & S. mauritianum & 25 & 0.4 & 0.3 & 0.61 & 127 \\
& S. mauritianum & 10 & 2.0 & 0.9 & 0.91 & 529 \\
& S. mauritianum & 19.1 & 2.9 & 1.2 & 0.13 & 748 \\
& S. mauritianum & 26.7 & 3.3 & 1.6 & 0.73 & 894 \\
& A. mearnsii & 25.6 & 3.4 & 1.8 & 0.71 & 949 \\
\hline
\end{tabular}

the indigenous trees measured. This tree was the tallest of the indigenous trees measured and was not shaded by other species. Given that this species is deciduous, it is important to note that this tree uses a minimal amount of water in the winter when water resources are limited. The indigenous $B$. salviifolia, measured using the SSS technique, had a similar water use to that of the lower climax species.

The daily summer water use of the A. mearnsii and the $E$. grandis was high in comparison to the indigenous species. These trees used between 18 and $27 \mathrm{Lday}^{-1}$ in the summer months and between 14 and $17 \mathrm{~L} \mathrm{day}^{-1}$ in the winter months. On average, the introduced species used 2.4 times more water than the average indigenous species. However, this is a direct comparison and would differ from upscaled comparisons due to the different stem densities of each species.

\subsection{Soil profile and water content}

The volumetric soil water content (VWC) measured at New Forest was highly responsive to rainfall events (Figs. 8 and 9). During the wet summer season, the VWC at the indigenous site 1 (Fig. 6) ranged from $27 \%$ in the upper horizon to $35 \%$ in the lower horizon. This indicated a higher clay content in the lower horizon. Towards the dry season, as the vegetation continues to use water, the VWC was depleted to 
(a) Daily water use of S. pyroides ( $\varnothing 98 \mathrm{~mm}$ ) at New Forest

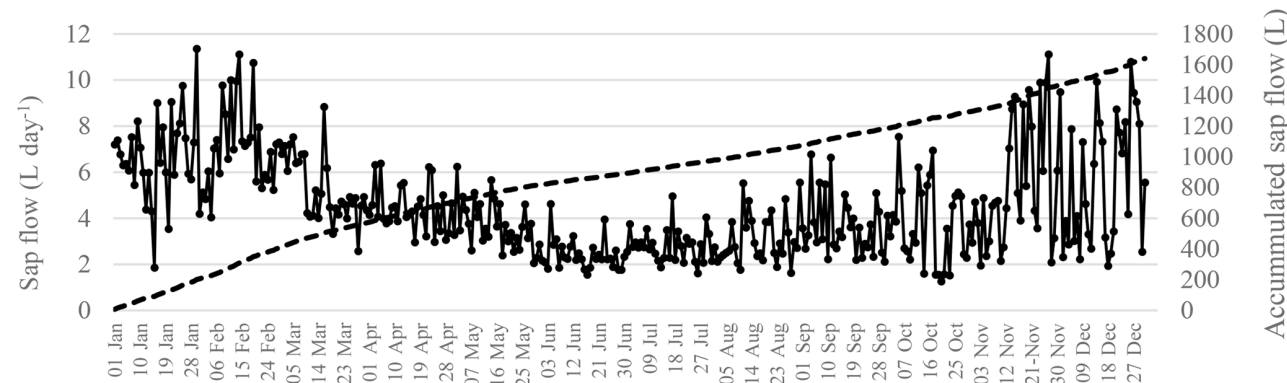

(b) Daily water use of C. africana (Ø $102 \mathrm{~mm}$ ) at New Forest

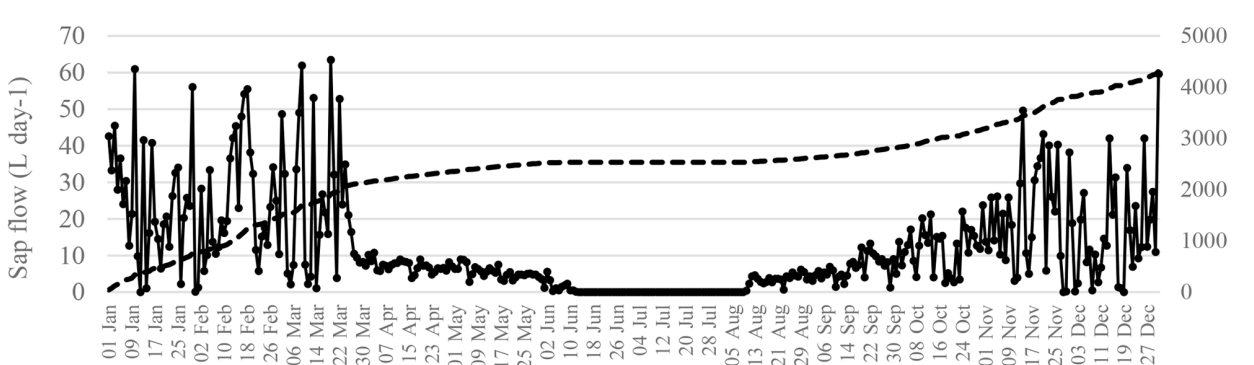

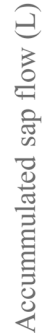

(c)

Daily water use of G. buxifolia $(\varnothing 114 \mathrm{~mm})$ at New Forest

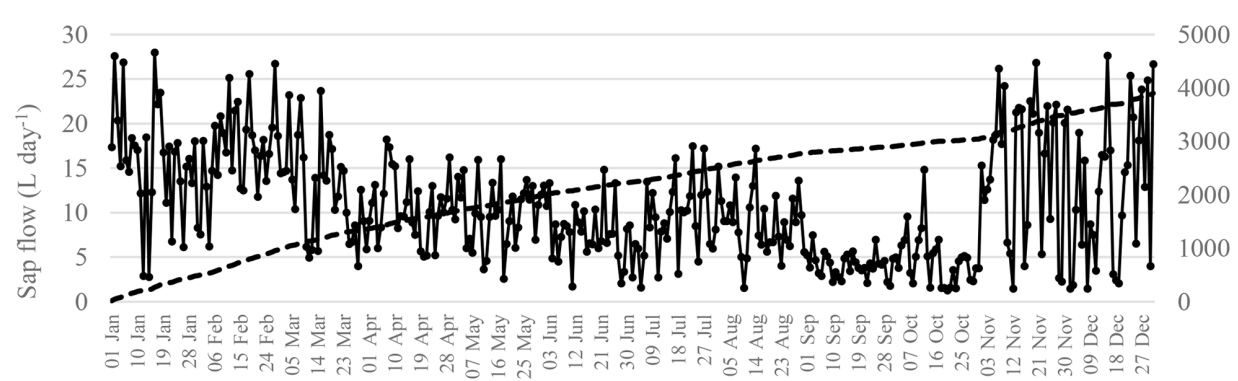

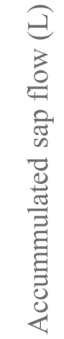

(d) Daily water use of $A$. mearnsii (Ø: $131 \mathrm{~mm})$ at New Forest

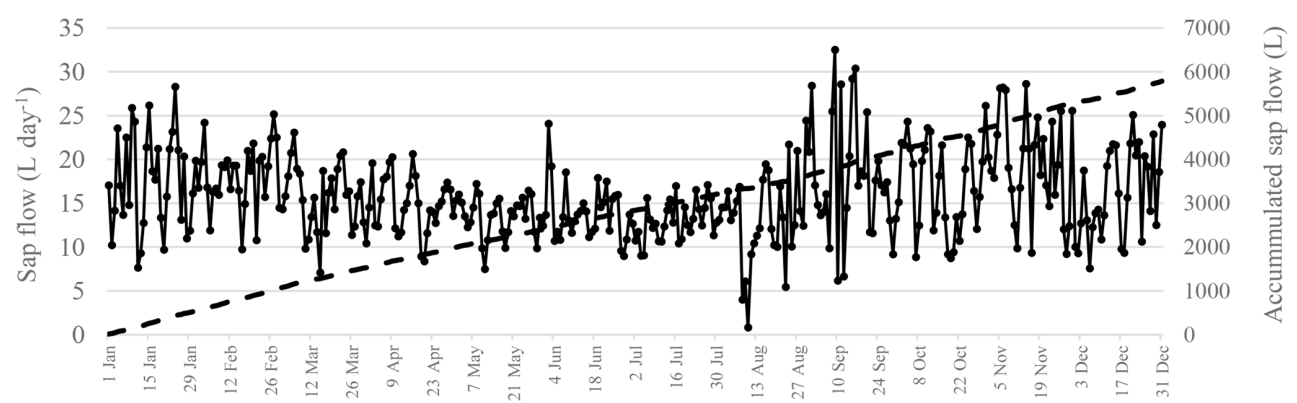

Figure 6. Daily sap flow (dotted line) and accumulated sap flow (dashed line) averaged over 2 years (2013 and 2014) from an indigenous $S$. pyroides (a), C. africana (b), G. buxifolia (c) and an introduced A. mearnsii (d) at New Forest.

$10 \%$ in the upper horizons. At the introduced site 2 , the soils were uniform throughout the horizons. During the summer periods, the profile soil water averaged $27 \%$, whereas it depleted to $9 \%$ or $11 \mathrm{~mm}$ of water per $100 \mathrm{~mm}$ depth of soil during the dry periods.
The soils had a dry bulk density $(\rho b)$ of $1.22 \mathrm{~g} \mathrm{~cm}^{-3}$, a particle density $\left(\rho_{\text {particle }}\right)$ of $2.54 \mathrm{~g} \mathrm{~cm}^{-3}$ and a porosity 0.52 , typically characteristic of sandy-loam soils. Introduced forestry species are known to have deep rooting systems, with observations of greater than $8 \mathrm{~m}$ in South Africa (Everson et al., 2006). This suggested that, during dry periods, 


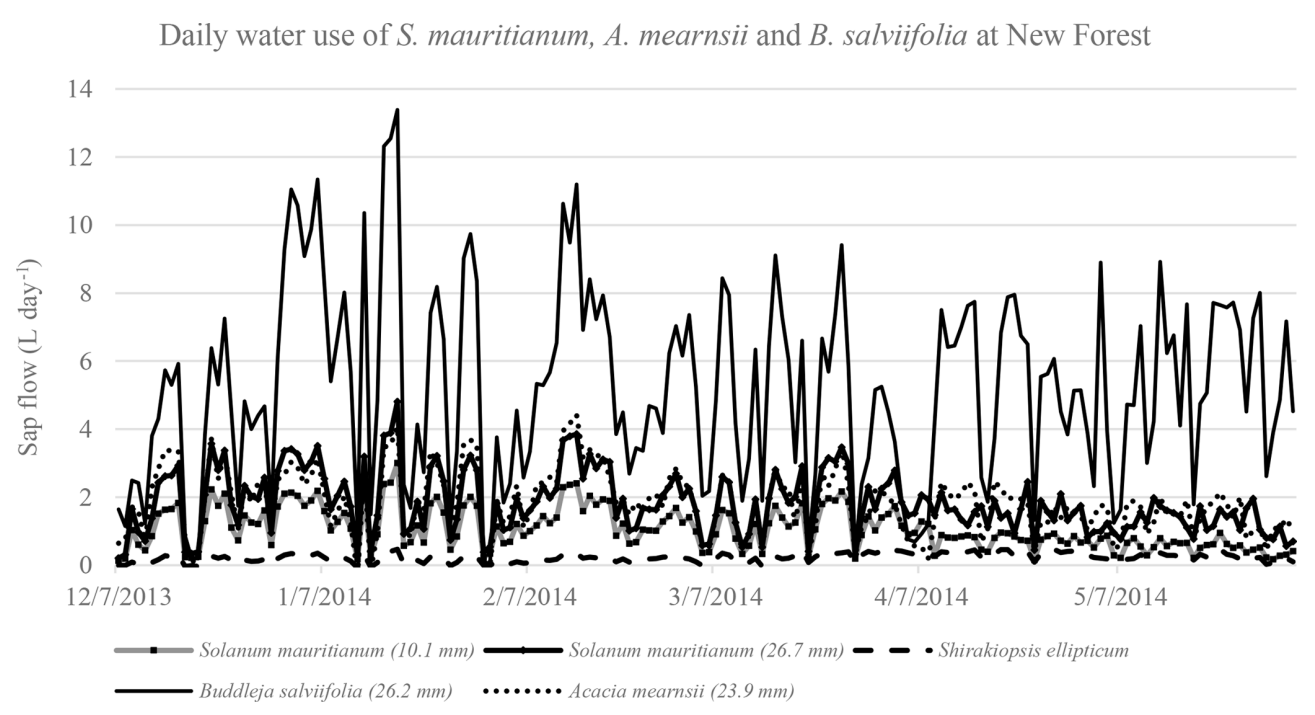

Figure 7. Daily water use for three S. mauritianum, a multi-stemmed B. salviifolia and an A. mearnsii using the SSS technique.

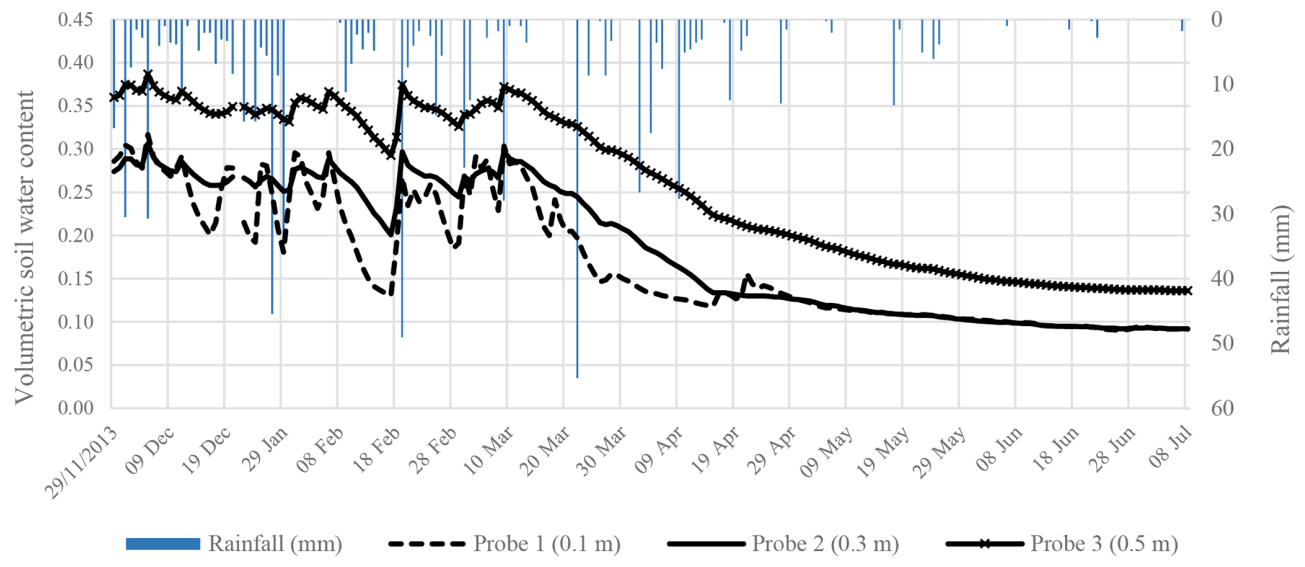

Figure 8. Hourly volumetric soil water content and the hourly rainfall at site 1 at New Forest.

this stand can access water from deeper layers in the soil profile. However, given the shallow depth of all the soils and the close proximity of the sites to the stream, it is clear that the vegetation in this area was not limited by water availability.

The VWC at both sites did not respond significantly to rainfall events under $6 \mathrm{~mm} \mathrm{~h}^{-1}$ except during consecutive events. Based on seasonally high transpiration rates we conclude that deep rooted plants in the riparian zone at the site are energy flux limited rather than moisture limited.

\subsection{Upscaling tree water use}

The results obtained from both the HPV and SSS techniques were used to determine an actual annual water use per unit area of the invaded mistbelt forest. Two hypothetical scenarios, a pristine forest and a heavily invaded forest, were also tested. Using the stem density per size class taken from ecological research completed in the area (Everson et al., 2016), stands of forest were compared. As the forest did not have a closed canopy, understorey trees were numerous as more photosynthetically active radiation (PAR) was available throughout the stand. The water use for a 2-year average of the riparian forest in its current state ( $21 \%$ invaded) was upscaled for all species and size classes. The total stand water use was approximately $3.3 \mathrm{ML} \mathrm{ha}^{-1} \mathrm{a}^{-1}\left(330 \mathrm{~mm} \mathrm{a}^{-1}\right)$. This was $29 \%$ of the average annual precipitation recorded during the monitoring period $\left(1030 \mathrm{~mm} \mathrm{a}^{-1}\right)$.

Two hypothetical scenarios were applied using the existing size class distribution for each species class and extrapolated based on an assumed invasion level. Assuming that the site was rehabilitated to a more pristine state, using stem density for non-invaded areas, the upscaled indigenous stand would use $2.39 \mathrm{ML} \mathrm{ha}^{-1} \mathrm{a}^{-1}\left(239 \mathrm{~mm} \mathrm{a}^{-1}\right)$. This would be $21 \%$ of the average annual precipitation. If the stand were to degrade further and become heavily invaded, the upscaled invaded stand would use $4.88 \mathrm{ML} \mathrm{ha}^{-1} \mathrm{a}^{-1}\left(488 \mathrm{~mm} \mathrm{a}^{-1}\right)$. This would be $43 \%$ of the average annual precipitation. Based on 


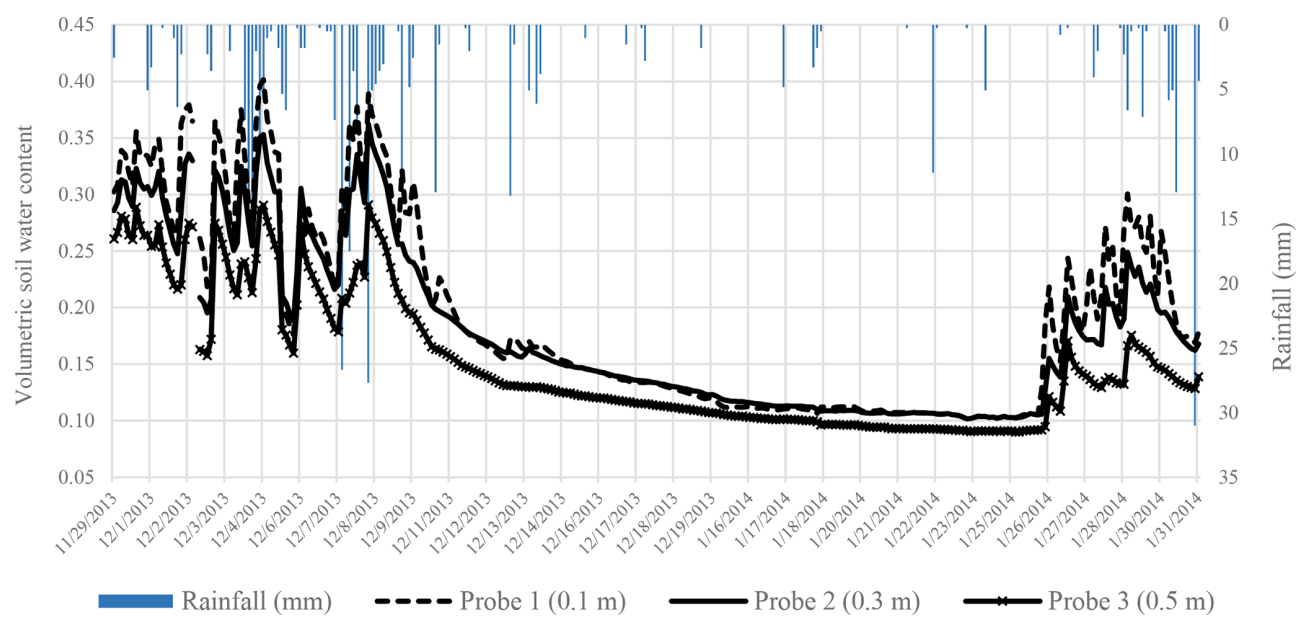

Figure 9. Hourly soil volumetric water content and the hourly rainfall at site 2 at New Forest.

these results we conclude that the invaded stand uses $40 \%$ more water per unit area annually than a pristine indigenous stand. If the stand were to become heavily invaded, a 2 -fold increase in water use would occur (104\% increase) with concomitant impacts on the water balance (streamflow). The inter- and intra-species water-use variations, particularly within the heterogenous indigenous stand, highlight the importance of good replications of a representative sample tree species and size classes. The results also show that it is important to highlight the slope position, physiological characteristics and climatic variations occurring during measurement periods.

Due to the prevalence of severe droughts in this area, these results are more likely to provide substance to land managers and decision makers, indicating the hydrological benefit of restoration and rehabilitation activities.

\section{Discussion and conclusion}

In South Africa, it has been well documented that introduced commercial tree species, in contrast to indigenous tree species, use more water and if removed would result in a net hydrological gain (Olbrich et al., 1996; Dye et al., 2001, 2008; Everson et al., 2007; Gush and Dye, 2008, 2009, 2015). The greater sapwood area in introduced species, as well as their fast establishment, tree density and rapid growth, results in a greater transpiration rate than indigenous species per unit area. The HPV and SSS techniques have been used, both locally and internationally, on numerous vegetation types. The accuracy of these measurements has been validated using gravimetric methods (Burgess et al., 2001; Granier et al., 2001; O'Grady et al., 2006; Steppe et al., 2010; Vandegehuchte and Steppe, 2013; Uddin et al., 2014; Forster, 2017). In South Africa, the HPV technique has been shown to provide accurate estimates of sap flow in both introduced tree species such as Acacia mearnsii, Pinus pat- ula and Eucalyptus nitens and indigenous tree species such as Rapanea melanophloeos, Podocarpus henkelii and Celtis africana (Smith and Allen, 1996; Dye et al., 2001, 2008; Everson et al., 2007). There is consensus in the literature that rehabilitation or restoration measures can result in the maximization of benefits such as goods and services, while minimizing water consumption (Gush, 2011).

A recent study showed that introduced stands could use up to 6 times more water than indigenous species in the riparian area (Scott-Shaw et al., 2017). However, this difference was largely related to stem density at a site where high winter rainfall and deep sandy soils were conducive to a highdensity mature introduced stand. The stand at New Forest, which was highly disturbed and was in a constant state of recovery, did not have a high stem density of mature trees in its current state. The measurements undertaken at this site have allowed for an accurate direct comparison of indigenous and introduced tree water use. Additionally, the measurements of trees growing in the understorey have provided interesting findings, indicating significant water use in the subcanopy layer. The results showed that individual tree water use is largely inter-species specific. As the introduced species remain active during the dry winter periods, their cumulative water use is significantly greater than that of the indigenous species. Small tress $(<30 \mathrm{~mm})$ in the understorey can use up to $2000 \mathrm{~L} \mathrm{a}^{-1}$, which is important for upscaling to stand water use. Upscaled comparisons showed that, due to the invasion by $A$. mearnsii and E. grandis $(21 \%)$, the stand water use has increased by $40 \%$. This is an important finding as it provides clear evidence to justify the hydrological benefit of clearing programmes. If the stand were to be completely invaded at the same stem density as the indigenous stand, the water use would double for this particular area. The findings from the understorey suggest that the water use from this zone should not be excluded from future studies, especially where there is no canopy closure. The promotion of 
indigenous deciduous trees for rehabilitation or clearing programmes may be important as there would be no transpiration during periods when water resources are limited.

Spatial estimates of evapotranspiration are required but are difficult to obtain in remote areas with limited aerodynamic reach. Remote sensing could be one area where this could be useful given appropriate validation. However the nature of the "thin" riparian strip will require finer scales than provided by most remote sensing products used for evaporation modelling (e.g. Landsat 8). The use of drones could provide the best option for these narrow riparian strips in the subsequent studies. Management dynamics are important in these environments. There is potential for these data to be used in a modelling framework with specific inputs for invaded mixed riparian forests. This would provide a suitable land management tool.

Data availability. The data used in this study can be requested by contacting the corresponding author.

Author contributions. BCSS performed the field work, data processing, and report compilation. CSE performed the field work, report compilation, and report review.

Competing interests. The authors declare that they have no conflict of interest.

Acknowledgements. The research presented in this paper forms part of an unsolicited research project (Rehabilitation of alien invaded riparian zones and catchments using indigenous trees: an assessment of indigenous tree water use) that was initiated by the Water Research Commission (WRC) of South Africa. The project was managed and funded by the WRC, with co-funding and support provided by the Department of Economic Development, Tourism and Environmental Affairs (EDTEA). The land owner, Alfie Messenger, of the New Forest farm is acknowledged for allowing field work to be conducted on their property. Assistance in the field by Alistair Clulow, Allister Starke and Siphiwe Mfeka is much appreciated.

Edited by: Dominic Mazvimavi

Reviewed by: Timothy Dube and two anonymous referees

\section{References}

Acocks, J. P. H.: Veld types of South Africa. 3nd edition, Mem. Botanical Survey of South Africa, 57, 1-146, 1988.

Allen, S. J. and Grime, V. L.: Measurements of transpiration from savannah shrubs using sap flow gauges, Agr. Forest Meteorol., 75, 23-41, 1994.

Askey-Dorin, M., Petit, N., Robins, L., and McDonald, D.: The role of vegetation in riparian management, in: Riparian Land Man- agement Technical Guidelines, Vol. 1. Principles of Sound Management, edited by: Lovett, S. and Price, P., LWRRDC Canberra, 97-120, 1999.

Burgess, S. O., Adams, M. A., Turner, N. C., Beverly, C. R., Ong, C. K., Khan, A. A. H., and Bleby, T. M.: An improved heat pulse method to measure low and reverse rates of sap flow in woody plants, Tree Physiol., 21, 589-598, 2001.

Clulow, A. D., Everson, C. S., Price, J. S., Jewitt, G. P. W., and Scott-Shaw, B. C.: Water-use dynamics of a peat swamp forest and a dune forest in Maputaland, South Africa, Hydrol. Earth Syst. Sci., 17, 2053-2067, https://doi.org/10.5194/hess-17-20532013, 2013.

Crowson, J.: Ezemvelo KZN Wildlife, Integrated Management Plan: uMngeni Veli Nature Reserve, South Africa, Ezemvelo KZN Wildlife, Pietermaritzburg, 67, 2008.

Cullis, J., Görgens, A., and Marais, C.: A strategic study of the impact of invasive alien vegetation in the mountain catchment areas and riparian zones of South Africa on total surface water yield, Water SA, 33, 35-42, 2007.

Dye, P. J.: Modelling growth and water-use in four Pinus patula stands with the 3-PG process-based model, Southern African Forestry Journal, 191, 53-63, 2001.

Dye, P. J., Gush, M. B., Everson, C. S., Jarmain, C., Clulow, A., Mengistu, M., Geldenhuys, C. J., Wise, R., Scholes, R. J., Archibald, S., and Savage, M. J.: Water-use in relation to biomass of indigenous tree species in woodland, forest and/or plantation conditions, Water Research Commission Report No. 361/08, ISBN 978-1-77005-744-9, Water Research Commission, Pretoria, South Africa, 156 pp., 2008.

Everson, C. S., Gush, M. B., Moodley, M., Jarmain, C., Govender, M., and Dye, P. J.: Effective management of the riparian zone vegetation to significantly reduce the cost of catchment management and enable greater productivity of land resources, Water Research Commission Report No. 1284/1/07, ISBN 978-177005-613-8, Pretoria, South Africa, 92 pp., 2007.

Everson, C., Scott-Shaw, B. J., Starke, A. P., Geldenhuys, C. J., Atsame-Edda, A., and Shutte, S.: Rehabilitation of Alien Invaded Riparian Zones and Catchments Using Indigenous Tree: An Assessment of Indigenous Tree Water-use: K5/2081, Water Research Commission Report No. 2081/1/16, Pretoria, South Africa, 2016.

Ford, C. R., McGuire, M. A., Mitchell, R. J., and Teskey, R. O.: Assessing variation in the radial profile of sap flux density in Pinus species and its effect on daily water-use, Tree Physiol., 24, 241-249, 2004.

Forster, M. A.: How Reliable Are Heat Pulse Velocity Methods for Estimating Tree Transpiration?, Forests, 8, 350, https://doi.org/10.3390/f8090350, 2017.

Fritzsche, F., Abate, A., Fetene, M., Beck, E., Weise, S., and Guggenberger, G.: Soil-plant hydrology of indigenous and exotic trees in an Ethiopian montane forest, Tree Physiol., 26, 10431054, 2006.

Granier, A., Loustau, D., and Bréda, N.: A Generic Model of Forest Canopy Conductance Dependent on Climate, Soil Water Availability and Leaf Area Index, Annuals of Forest Science, 57, 755765, 2001.

Grime, V. L. and Sinclair, F. L: Sources of error in stem heat balance sap flow measurements, Agr. Forest Meteorol., 94, 103121, 1999. 
Gush, M. B. and Dye, P. J.: Water-use Measurements of Selected Woodland Tree Species within the Kruger National Park, CSIR, Agrometeorology, School of Environmental Sciences, University of KwaZulu-Natal, Scottsville, South Africa, 2008.

Gush, M. B. and Dye, P. J.: Water-Use Efficiency Within a Selection of Indigenous and Exotic Tree Species in South Africa as Determined Using Sap Flow and Biomass Measurements, CSIR, Agrometeorology, School of Environmental Sciences, University of KwaZulu-Natal, Scottsville, South Africa, 2009.

Gush, M. B.: Water-use, growth and water-use efficiency of indigenous tree species in a range of forest and woodland systems in South Africa, PhD dissertation, Department of Botany, University of Cape Town, 2011.

Gush, M. B., de Lange, W. J., Dye, P. J., and Geldenhuys, C. J.: Water-use and Socio-Economic Benefit of the Biomass of Indigenous Trees, Volume 1, Research Report, 2015.

Jewitt, G.: Integrating blue and green water flows for water resources management and planning, Phys. Chem. Earth A, B, C, 31, 753-762, 2006.

Kotzé, I., Beukes, H., van Den Berg, E., and Newby, T.: National Invasive Alien Plant Survey. Report No. GW/A/2010/21, Agricultural Research Council - Institute for Soil, Climate and Water Pretoria, 2010.

Marshall, D. C.: Measurement of sap flow in conifers by heat transport, Plant Physiol., 33, 385-396, 1958.

Miller, G. R., Xingyuan, C., Yoram, R., and Baldocchi, D. D.: A new technique for upscaling sap flow transpiration measurements to stand or land use scale fluxes, Civil and Environmental Engineering, University of California, Berkeley, 2007.

Mucina, L. and Rutherford, M. C.: The vegetation of South Africa, Lesotho and Swaziland, Strelitzia 19, South African National Biodiversity Institute, Pretoria, 2011.

Nosetto, M. D., Jobbagy, E. G., and Paruelo, J. M.: Landuse change and water losses: the case of grassland afforestation across a soil textural gradient in central Argentina, Glob. Change Biol., 11, 1101-1117, 2005.

O'Grady, A. P., Cook, P. G., Howe, P., and Werren, G.: An assessment of groundwater-use by dominant tree species in remnant vegetation communities, Pioneer Valley, Queensland, Aust. J. Bot., 54, 155-171, 2006.

Olbrich, B., Olbrich, K., Dye, P. J., and Soko, S. A.: YearLong Comparison of Water-use Efficiency of Stressed and NonStressed E. grandis and P. patula: Findings and Management Recommendations, CSIR report FOR-DEA 958, CSIR, Pretoria, South Africa, 1996.

Pooley, E.: Mountain flowers: A field guide to the flora of the Drakensberg and Lesotho, Natal Flora Publications Trust, Durban, 2003.

Richardson, D. M., Rouget, M., Ralston, S. J., Cowling, R. M., van Rensburg, B. J., and Thuiller, W.: Species richness of alien plants in South Africa: Environmental correlates and the relationship with indigenous plant species richness, Ecoscience, 12, 391-402, 2005.

Savage, M. J., Graham, A. N. D., and Lightbody, K. E.: An investigation of the stem steady state heat energy balance technique in determining water-use by trees, Water Research Commission, 348, 1-168, 2000.
Schulze, R. E.: Mapping mean monthly temperature distributions for Natal by trend surface analysis, S. Afr. J. Sci., 78, 246-248, 1982.

Scott, D. F.: Managing riparian zone vegetation to sustain streamflow: Results of paired catchment experiments in South Africa, Can. J. Forest Res., 29, 1149-1157 1999.

Scott, D. F. and Lesch, W.: The effects of riparian clearing and clearfelling of an indigenous forest on streamflow, stormflow and water quality, S. Afr. For. J., 175, 1-14, 1996.

Scott-Shaw, B. C., Everson, C. S., and Clulow, A. D.: Water-use dynamics of an alien-invaded riparian forest within the Mediterranean climate zone of the Western Cape, South Africa, Hydrol. Earth Syst. Sci., 21, 4551-4562, https://doi.org/10.5194/hess-214551-2017, 2017.

Smith, D. and Allen, S.: Measurement of sap flow in plant stems, J. Exp. Bot., 47, 1833, https://doi.org/10.1093/jxb/47.12.1833, 1996.

Steppe, K., De Pauw, D. J. W., Doody, T. M., and Teskey, R. O.: A comparison of sap flux density using thermal dissipation, heat pulse velocity and heat field deformation methods, Laboratory of Plant Ecology, Department of Applied Ecology and Environmental Biology, Faculty of Bioscience Engineering, Ghent University, Coupure links 653, 9000 Gent, Belgium, 2010.

Turpie, J. K., Marais, C., and Blignaut, J. N.: The working for water programme: Evolution of a payments for ecosystem services mechanism that addresses both poverty and ecosystem service delivery in South Africa, Ecol. Econ., 65, 788-798, 2008.

Uddin, J., Smith, R., Hancock, N., and Foley, J.: Evaluation of Sap Flow Sensors to Measure the Transpiration Rate of Plants during Canopy Wetting and Drying, Journal of Agricultural Studies, 2, https://doi.org/10.5296/jas.v2i2.6134, 2014.

Vandegehuchte, M. W. and Steppe, K.: Sap-flux density measurement methods: working principles and applicability. Laboratory of Plant Ecology, Faculty of Bioscience Engineering, Ghent University, Coupure links 653, 9000 Gent, Belgium, 2013.

van Wilgen, B. W., Richardson, D. M., Le Maitre, D. C., Marais, C., and Magadlela, D.: The Economic Consequences of Alien Plant Invasions: Examples of Impacts and Approaches to Sustainable Management in South Africa, Journal of Environmental, Development and Sustainability, 3, 145-168, 2001.

Van Wilgen, B. W., Davies, S. J., and Richardson, D. M.: Invasion science for society: A decade of contributions from the Centre for Invasion Biology, S. Afr. J. Sci., 110, a0074, https://doi.org/10.1590/sajs.2014/a0074, 2014.

Wal, R. V. D., Truscott, A. M., Pearce, I. S. K., Cole, L., Harris, M. P., and Wanless, S.: Multiple anthropogenic changes cause biodiversity loss through plant invasion, Glob. Change Biol., 14, 1428-1436, 2008.

Yepez, E. A., Huxman, T. E., Ignace, D. D., English, N. B., Weltzin, J. F., Castellanos, A. E., and Williams, D. G.: Dynamics of transpiration and evaporation following a moisture pulse in semiarid grassland: a chamber-based isotope method for partitioning flux components, Agr. Forest Meteorol., 132, 359-376, 2005. 